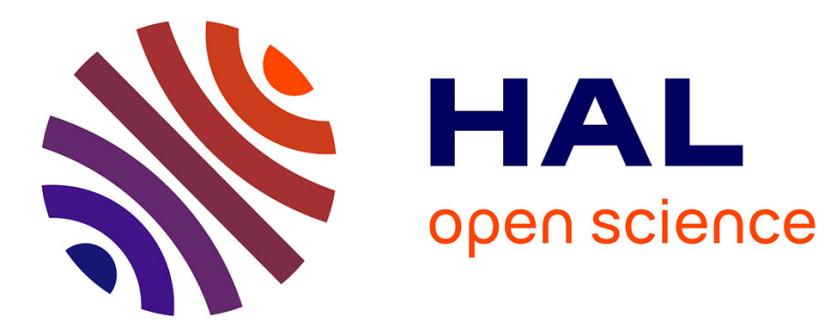

\title{
Number systems in the Adamawa branch of Niger-Congo
}

Raymond Boyd

\section{To cite this version:}

Raymond Boyd. Number systems in the Adamawa branch of Niger-Congo. African languages and cultures, 1989, 2 (2), pp.149-173. 10.1080/09544169008717714?journalCode=cjac19 . hal-01297111

\section{HAL Id: hal-01297111 \\ https://hal.science/hal-01297111}

Submitted on 2 Apr 2016

HAL is a multi-disciplinary open access archive for the deposit and dissemination of scientific research documents, whether they are published or not. The documents may come from teaching and research institutions in France or abroad, or from public or private research centers.
L'archive ouverte pluridisciplinaire HAL, est destinée au dépôt et à la diffusion de documents scientifiques de niveau recherche, publiés ou non, émanant des établissements d'enseignement et de recherche français ou étrangers, des laboratoires publics ou privés. 
Je reprends ici un article publié en 1989. Dans cette version, on y trouvera quelques mises à jour ainsi que la correction d'erreurs typographiques. Au 1 avril 2016 et malgré son ancienneté, l'original est toujours en vente au 1 avril 2016 à

http://www.tandfonline.com/doi/abs/10.1080/09544169008717714?journalCode = cjac19 Il peut également être consulté à http://www.jstor.org/journal/afrilangcult. 
African Languages and Cultures 2,2 (1989): 149-173.

\title{
NUMBER SYSTEMS IN THE ADAMAWA BRANCH OF NIGER-CONGO
}

\author{
Raymond Boyd
}

\section{Introduction}

This paper has two parts, which are presented as separate entities, but are nevertheless interrelated and therefore cross-referenced.

The first part attempts to show that the diversity of roots for 'one' and 'two' in the Adamawa languages is apparent rather than real, and that, given certain morphological hypotheses, fairly widespread roots are reconstructible.

The second part concerns the structure and range of variation in the number systems from one to twenty in two Adamawa groups. The first of these is composed of the languages in Greenberg's groups 2 (Chamba Leko), 4 (Duru), 5 (Mumuye/Yendang), and 8 (Kam). The roots for numerals in these languages are clearly related; furthermore, lexical similarities are equally apparent in the rest of their vocabularies (although the isolated language Kam is peripheral). All thus appear by simple inspection to be members of a single larger unit. The hypothetical genetic relationships within this unit, hereafter called Adamawa group A, are shown in Chart 1. 


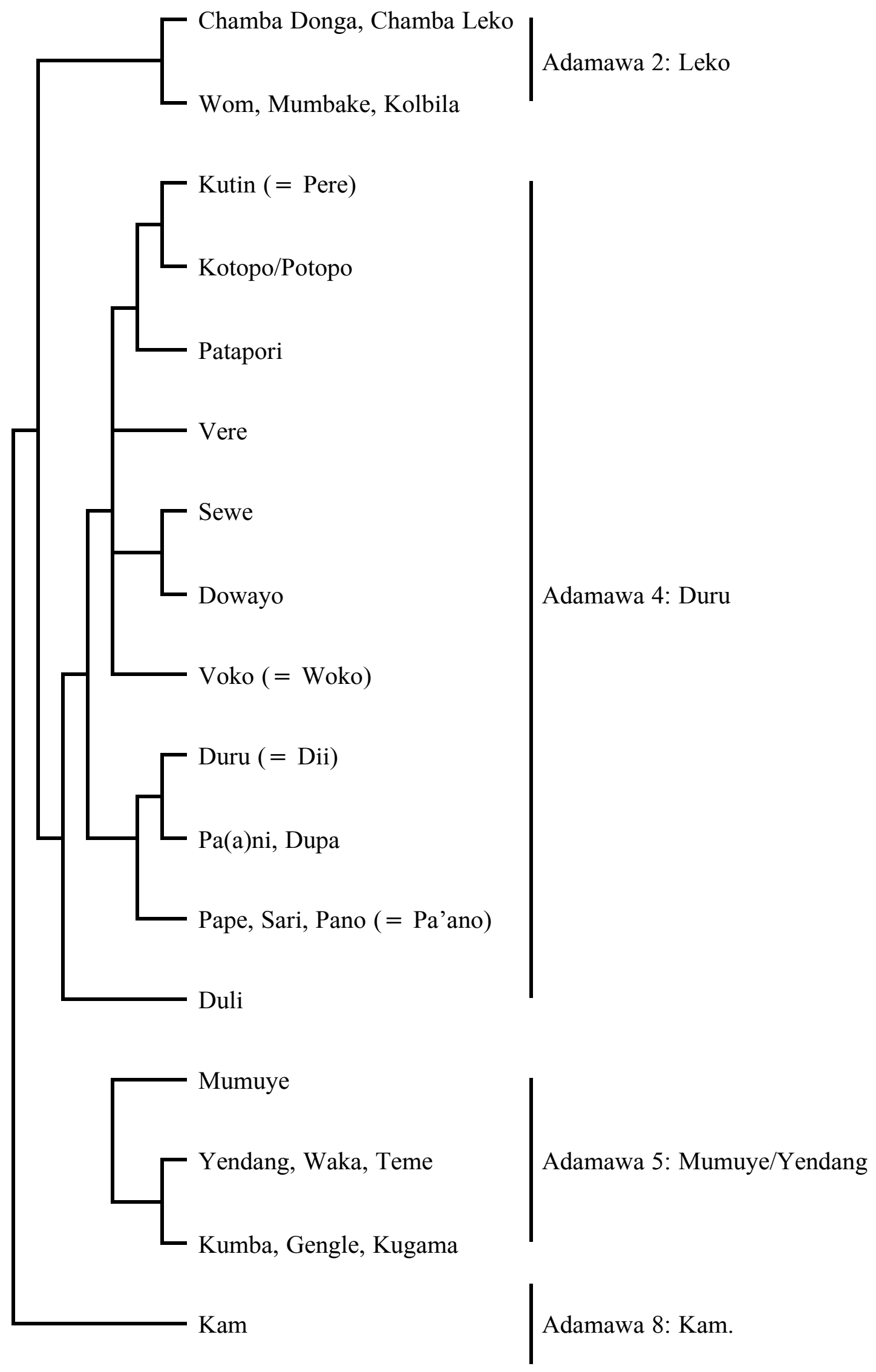

Chart 1: Adamawa group $A$ 
The second group is Greenberg's group 6 (Mbum), which is clearly differentiated from group $\mathrm{A}$ and within the rest of Adamawa. The composition and probable genetic relationships in group 6 are shown in Chart 2.

A. Northern

1. a. Tupuri

b. Mundang, Pam, Mono

c. Mangbai Mambai

2. Dama, Galke (= Ndáí)/Pormi, Kali

B. Central

1. Koh, Sakpu

2. Karang, Pana, Njak Mbai, Ngumi, Kaㅛ $\underset{\sim}{\varepsilon}$

C. Southem

Mbum, Mbere, Kpere - Kepere

Chart 2: Adamawa group 6

These two groups contain the majority of the populous and well documented Adamawa languages. At the same time, their intemal diversity helps to put the data for individual languages into perspective.

The following remarks are based on many sources, too many to allow reproduction of all the data, but a selection is tabulated in Appendix 2. The reader must however consult the following works if he wishes to verify in greater detail the conclusions reached.

Anonymous (1955/6): - Adamawa 1: Tula

Baudelaire (1944): - Adamawa 4 and 6: various languages

Blench \& Edwards (1988): - Adamawa 4: Vere

Bohnhoff (1972): - Adamawa 4: Dii

Fabre (2003): Adamawa 2: Leko

Gaudefroy-Demombynes (1907): - Adamawa 13: Bua

Griaule (1941): - Adamawa 4: various languages

Jungraithmayr (1968/9): - Adamawa 1: various languages; Adamawa 10: Longuda; also Burak

Lacroix (1962): - Adamawa 4: Duru; Adamawa 6: Galke

Meek (1931): - Adamawa 2: Leko, Wom, Mumbake; Adamawa 4: Vere; Adamawa 5: Mumuye, Yendang and closely related languages; Adamawa 7: Yungur and related languages; Adamawa 8: Kam; Adamawa 9: Jen and Munga; Adamawa 10: Longuda Mouchet (1938): - Adamawa 6: Northern group 
Mouchet (1954): - Adamawa 14: Juman

Noss (1976): - Adamawa 2: Leko

Nougayrol (1980): - Day

Pairault (1969): - Adamawa 13: Kulaal

Raen (1985): - Adamawa 4: Kutin

Rendinger (1949): - Adamawa 13: Bolgo

Shimizu (1979,1983): - Adamawa 5: Mumuye

Strümpell (1910, 1922/3): - Adamawa 2: Leko, Kolbila; Adamawa 4: various languages; Adamawa 6: various languages

Ubels (1981): - Adamawa 6: Karang, Koh

Williamson (1973): - Adamawa 4: Patapori

The published data are supplemented by, and compared with, my own unpublished data for diverse languages in Adamawa groups 4, 5 and 6.

\section{Adamawa roots for 'one' and 'two'}

\section{1. 'One'}

The terms for 'one' and 'two' in the Adamawa languages will often not appear to be cognate from simple inspection (unlike the roots for 'three' and 'four'). There are, however, ways of analysing them into component morphemes which make the reconstruction of widespread common roots more plausible.

All starred forms proposed below are, with the exception of the Mumuye examples (from Adamawa group 5) reconstructed by Shimizu (1979), not obtained by the application of the comparative method. They are simply hypotheses to be refined or disproven by methodological reconstruction, and for this reason are preceded (at least in their first occurrence) by the symbol $\sim$. If, however, number words constitute a unique class, grammatically and semantically, in these languages (as seems to be the case), irregularities may have appeared in correspondences, making fully convincing proof unobtainable.

Available evidence is presented for all Adamawa groups according to Greenberg's numbering, to the exclusion of groups 3 (Chamba Daka) and 11 (Fali), whose membership of the branch is in doubt. Data are, however, included for two other probable Adamawa members, Burak and Day.

There is evidence to suggest that a root $\sim^{*} \mathrm{KWIN}$ can be reconstructed with the meaning 'one' in the Adamawa branch.

Apparent cognates of this root are found in some Cross River 1 and Plateau 5-6 languages, according to Williamson's (1973) lists. She suggests these kVn forms may themselves be cognate with items in Ijo and Yoruba. Similar forms with a final oral rather than nasal consonant appear elsewhere in Cross River (notably in Efik). 
Another widespread root, which Williamson suggests may have been $\sim^{*}$ din in its earliest form, is represented in many other Cross River and Plateau languages. She cites the reconstructions *yin and *niug at the Proto-Jukunoid and Proto-Plateau levels, respectively.

Since, however, the latter root is found on occasion with a kV- prefix (see the data for Ufia in Cross River 2, and Yeskwa in Plateau 5), there may be a way to relate it to the root with initial velar.

A rather complicated hypothesis would, in fact, cover most of the Cross River/Plateau data:

Let us assume a single root, $\sim$ *DI (sometimes $\sim * \mathrm{DU}$ ), and two affixes, ${ }^{*}(\mathrm{~V}) \mathrm{K}(\mathrm{V})$ and $*(\mathrm{~V}) \mathrm{N}(\mathrm{V})$, which can appear, separately or together, as either prefixes or suffixes, or both.

To obtain the forms with initial velar, we may assume either an original $* \mathbf{K V}+\mathbf{N}$ $+\mathrm{DI}>\mathrm{KVNJI}>\mathrm{KVNYI}>\mathrm{KVNI}>\mathrm{KVN}$ or $* \mathrm{KV}+\mathrm{DI}>{ }^{*} \mathrm{KVD}$. Some support for this hypothesis is provided by the frequently observed inversion of the coronal and velar features: in most cases, where we find a term with initial velar, we find a final coronal nasal; and where we find an initial coronal, we find a final velar nasal. This can be explained by assuming prefixation of $* \mathrm{KV}-\mathrm{N}$ - in the former case, and suffixation of $*-\mathrm{N}-\mathrm{K}(\mathrm{V})$ in the latter.

There is also a small number of cases of initial unvoiced coronals (such as $t$, ts, $\int$; see Plateau la, 4 and 6). These may be derived in one of two ways: either $* \mathrm{~N}+\mathrm{DI}>\mathrm{NJI}>\mathrm{C}$, where loss of the initial nasal results in devoicing; or $* \mathrm{KU}>\mathrm{KW}>\mathrm{C}$, where a labialised velar becomes a palatal. (Little mention has been made of the latter process, but there are clear examples involving the Niger-Congo root for 'die' in various languages, e.g. in the Ubangi groups Banda and Sere-Ngbaka.)

Other languages display voiced velar initials. Their presence may be attributed either to backing: ${ }^{*} \mathrm{DI}>\mathrm{JI}>\mathrm{GI}$, or to labialisation and assimilation of an initial velar: ${ }^{*} \mathrm{KU}>$ $\mathrm{KW}>\mathrm{GW}>\mathrm{GB}$ (or BU).

An $\mathbf{i} / \mathbf{a}$ alternation in the root vowel may result from assimilation by open vowels in prefixes or suffixes.

The hypothetical Adamawa root can be considered cognate if we assume the historical development $*$ KU + DI $+\mathrm{N}>$ KUJIN $>$ KUYIN $>$ KWIN.

Some Adamawa languages, however, have reflexes suggesting an original *KWIT(V), with medial/final oral consonant. This seems to correspond to the Ekoid forms, apparently from $\sim *$ dit $>$ jit (sometimes $+{ }^{*} \mathbf{V N}+{ }^{*} \mathbf{K}>$ əy ?). There may thus be some third flexional morpheme which replaces, assimilates, or is assimilated by the *-N suffix in Adamawa.

Reflexes of the original Adamawa root must be sought in each language, not only with the meaning 'one', but also in terms for 'six' (usually compounded from 'five' + $($ connective + ) 'one'), 'nine' (often compounded of 'remains' + 'one', i.e. one more is 
required to complete ten (finger)), 'eleven' (always 'ten' + connective + 'one'), and sometimes 'twenty' (in languages where 'twenty' is taken as 'one person', i.e. the sum of the number of fingers and toes).

\subsubsection{Adamawa 1}

Tula has win, -in 'one' and nu.kun 'six' ('five one'). Dadiya has win 'one', nu.kun 'six'; Awak has din 'one'. idi.kuun 'six'. These languages may provide support for the prefixal nature of the initial $* \mathrm{~K}(\mathrm{~W})$ in the postulated common root. The prefix would seem to be absent in 'one' but present in the term for 'six'; but there may of course be another explanation for these data.

Awak 'one' may be the result of no prefixing, but may also be a borrowing from the Plateau group.

Cham is like the preceding languages in having nu.kun 'six', but may use a variant with *-AN instead of *-IN in kwaan 'one'. Compare wuru-wiin 'nine' (probably 'remains one'). Note that, in the other group 1 languages, 'nine' seems to derive from $\sim$ *T-UR-KOP (probably 'prefix-remains ten'), suggesting the compression in two different ways of an original 'remains one (for) ten' sequence, as observed in Adamawa 4 and 5 (see 3.1.9 below).

\subsubsection{Adamawa 2}

In these languages, 'six' is formed from 'five' and an element having the form guàs. This may be composed of two elements, the first of which is the *KWI- of the common root, with voicing assimilation of the initial velar (cf. the closely related group 4 below). The second, a suffix *-(A)S(A), is of uncertain origin, but could perhaps be compared with the suffix in Libo (Adamawa group 7) 'one'.

\subsubsection{Adamawa 4}

*KWIN appears as gun, gbun, bin in the languages of the Dowayo subgroup with the sense 'one'. In Voko wunga 'one', there may be an added suffix, or simply the transfer of the *Kfound initially in the protoform to a suffix position.

The Dii group has gúu 'six', which should also be cognate (see 3.1 below).

\subsubsection{Adamawa 5}

The two Mumuye roots for 'one', *gbétì and *gòrV, may be cognate with the nasalless variant of the common root. The former may have an additional alveolar suffix (i.e., from $\left.\sim^{*} \mathrm{KWI}(\mathrm{T}) . \mathrm{TI}\right)$.

In the Yendang subgroup, however, we find in(d)i as either 'one' or part of 'six' in various languages, suggesting an original $* \mathrm{~N}+\mathrm{DI}$. As 'one', the root may have a b- prefix (perhaps $<* \mathrm{KW}$-, cf. Adamawa 4); as 'six', the prefix may be an unidentified (a)t-. 


\subsubsection{Adamawa 6}

The Northern and Central groups have a root of the form mbéw for 'one', which may not be a reflex of the common root. The Southern group, however, uses són. This root, if not borrowed, may be derived from the original one. It must be remarked, however, that if the initial oral is derived from $\mathbf{n j}>\mathbf{c}$ ( $>\mathbf{s}$ in these languages with no palatal order), $\mathbf{- n}-$ must reappear as a suffix; and if derived from ${ }^{*} \mathrm{KW}>\mathrm{c}$, -k must reappear as a suffix (to explain the final velar nasal).

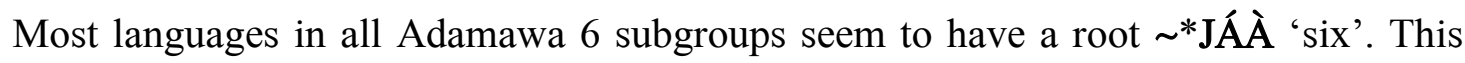
is reminiscent of the root found in Adamawa 8 (Kam), discussed below, and may therefore be a variant of 'one', formed in different morphological or syntactic conditions.

\subsubsection{Adamawa 7}

Yungur/Roba have -ini 'one' with a labial prefix f -.

The Mboi form fandi 'one' is likely to have resulted from prefixation of fa-.

Libo wunfat 'one' has a suffix -Sat, since 'one' in 'six' is represented by -onu.

In Yungur/Roba/Mboi, 'six' seems to be decomposable as a connective m-, the root -indi- 'one', and a velar suffix -ke.

\subsubsection{Adamawa 8}

Kam bimbimi 'one' seems to be a reduplicated form of *KWIN. The forms for 'six' (joop) and 'seven' (jub ira) remain unexplained, but a diachronic hypothesis relating them to *KWIN can be devised. Suppose an original form *NUN-KWI(N) 'five one' as in Adamawa group 1, and a similar development whereby the initial consonant becomes different in 'one' $(*(\mathbf{K})$ WIN $>*(\mathbf{g})$ win $>$ bin $)$ and 'six' $\left({ }^{*} \mathrm{KWI}(\mathrm{N})>*^{*} \mathrm{gwi}>\mathrm{ju}\right)$. This means that *NUN ( $>$ ngwun 'five' in Kam) can now be dropped from 'six' without danger of confusion, as may have happened in the Dii languages of Adamawa group 4. 'Seven' is then compounded from 'six', but in Kam, unlike Dii, by adjunction of the root for 'two', as if 'six' were still composed of 'five' and 'one'. In fact, there does appear to be a second component of unknown origin in 'six', namely, the bilabial suffix (reapplication of a reduced form of 'one'?).

\subsubsection{Adamawa 9}

Jen tsuy 'one' and Munga tsin 'one' (which becomes con in 'six', perhaps the result of an original $* \mathrm{I} / * \mathrm{~A}$ alternation) are comparable to the form in the Southern group of Adamawa 6 .

\subsubsection{Adamawa 10}

The Longuda root is kal, which one would hope to be able to derive from an earlier *KWAT. 


\subsubsection{Adamawa 12}

Nimbari/Nyamnyam (n)yeme or geme (3eme ?) appears to be unrelated to the common root.

\subsubsection{Adamawa 13}

Lwa (Niellim) 6úrū and Bua gulu 'one' may be derivable from an original *KWIT, and Bolgo/Koke bara(k) 'one' from *KWAT, which receives a velar suffix in some dialects. Kulaal tón 'one' seems rather to be comparable to the forms in Adamawa 6 and 9.

\subsubsection{Adamawa 14}

Juman du 'one' recalls the Plateau/Cross River root posited as giving rise to ${ }^{*} \mathrm{KWIN}$ by affixation. Comparison should show whether the initial injective and the back vowel are in fact reflexes resulting from earlier affixes.

\subsubsection{Burak}

Burak has kwin 'one', apparently conserving the initial root, but naa sin 'six', where kw seems to have been fronted.

\subsubsection{Day}

Day has ngŏy 'one' but mòn in 'six'. In this case, the attempt could be made to reconstruct $* \mathrm{KWIN}-\mathrm{K}$ and $*(\mathbf{K}) \mathrm{WAN}$, respectively, assuming nasal harmonisation of the initial consonant. The difference in tone remains unexplained.

\subsubsection{Summary}

In sum, support for the hypothesis of reconstructing *KWIN 'one' at a common Adamawa level is most likely to be found in groups 1, 4, 8, Burak, and Day. Suggestions of an alternate *KWAN are observed in groups 1, 13, and Day.

Suggestions of a variant *KWIT are found in the Mumuye part of group 5 and in parts of group 13 (perhaps also *KWI- in group 2 and part of group 4), with the possibility of a corresponding *KWAT in group 10.

There are, however, isolated instances suggesting the possibility of reconstructing an original *NDI- 'one'. These are found in group 1 (where borrowing is nevertheless the most likely source), the Yendang part of group 5, group 7 (closely resembling Yendang), and group 14 (with a similar form in a set of languages in group 13). If this root is also part of Common Adamawa, it must be assumed that the position of the nasal element as prefix or suffix was still undetermined at the time of the earliest dialectisation, and subsequently became fixed in each individual group. Where $* \mathbf{N}$ was suffixed, $* \mathrm{KU}$ was prefixed, and the root-initial $* \mathrm{D}$ became $* \mathrm{Y}$. 
In groups 6, 9, 13 and Burak, we find cases of voiceless initial coronals and final velar nasals. Discovering the exact source of these forms is an interesting unresolved problem.

\section{2. ' $T W O$ '}

Comparison of terms for 'two', 'seven' (often 'five' + (connective + ) 'two'), 'twelve' ('ten' + connective + 'two'), and 'twenty' (in languages which treat 'twenty' as 'two sets of ten') leaves little doubt that a root *ITO can be reconstructed with the meaning 'two' in the Adamawa languages. There are, however, a certain number of cases which deserve special examination.

\subsection{1. rop}

Some languages have a word resembling rop for 'two'. These are:

\begin{tabular}{|c|c|}
\hline Adamawa 1: & Tula \\
\hline Adamawa 7: & Roba/Libo \\
\hline Adamawa 13: & Kulaal \\
\hline Burak: & \\
\hline
\end{tabular}

Williamson (1973) lists similar forms in Plateau group 1 and one Jarawan Bantu language. She recalls their presence in Chadic Bauchi and Tera as well, but suggests the latter have borrowed from Plateau.

These forms may be related to *ITO by supposing a suffix *-(A)P (or *-(A)B, with devoicing characteristic of a reduced consonant inventory in final position). *-T- is then weakened intervocalically to *-R-, as in many Adamawa languages with straightforward reflexes of *ITO, and *I- is dropped.

(Note that, in 'twelve' to 'seventeen', Tula shows yi- prefixed to the roots for 'two' to 'five'. A vowel copied from the first root vowel is generated before root-initial sonorants, giving y-or-op yorau '(ten +) two'; cf. Dadiya yoo and Awak y??? 'two'. This prefix is probably secondary and not the source of the initial *I- in *ITO.)

The same suffix also appears in group 1 in *NAAR-AP 'eight', derived from *NAAR 'four'. (Dadiya naar 'four' is the only group 1 language to conserve the original final liquid, showing that the segmentation is not NAA-RAP 'four-two'.) Compare this situation with 'Bantoid' Vute: 6ūurúp 'two', nà:sùp 'four'.

(Note that in Tula, 'eight' in 'eighteen', unlike 'two' in 'twelve', does not take the yi- prefix. This may reflect differing consciousness of the relation of derivation in the two cases.)

But now let us look at 'seven' in group 1, where most languages suggest an original $\sim^{*}$ NIBIR. The data from the rest of Adamawa lead us to expect that, if 'seven' is not 
composed of 'three' (and nothing suggests that this is the case), it will be composed of 'two' (see 2.2.2 below). Let us therefore suppose an original 'five two' in which $\sim^{*} \mathrm{NU}->\sim * \mathrm{NI}-$ by vowel harmonisation (thus not $\sim^{*} \mathrm{NYAR}$ 'four' $>\sim^{*} \mathrm{NI}$ ), since all group 1 languages but one (Awak, which seems to have borrowed Chadic 'four' as fwáát 'five'!) have this common Adamawa root for 'five'.

The intervocalic *-B- must now be assigned either to the part of the compound representing 'five' or to the one representing 'two'. If *-B- is part of 'five', 'two' will appear in 'seven' as *-IT, a shortened form of *ITO. If, however, *-B- is joined with *-IR, we may hypothesise that an earlier *-B suffix has been shifted to prefix position.

This hypothesis is the inverse of Williamson's (1973) suggestion (citing Carl Hoffmann) that the Plateau forms cognate with Adamawa rop 'two' result from reanalysis of reflexes of the root found in Proto-Bantu as *-bàdí 'two' (presumably as *bà-dí with class 2 prefix). She thereby seems to imply that the reanalysed prefix was then shifted to suffix position. The Vute forms cited above nevertheless leave open the possibility that reanalysis occurred after a suffix was already in place.

Unfortunately, the group 1 data are not sufficient for a straightforward assignment of the intervocalic consonant to one part of the compound or the other. Awak, which has dropped the Adamawa root for 'five', has (idi)bər 'seven', suggesting that *-BIR was interpreted as a unit. But Cham nowo 'five', compared with Voko nombo (in Adamawa 4) and Burak no:b outside group 1, raises the possibility of reconstructing a *NUP 'five' alongside the more common $*$ NUN found in other groups.

If the segmentation *NI-BIR could be established for 'seven', the Tula data could be used in support of a further historical hypothesis, namely, that the roots for 'one' and 'two' are in fact identical. Thus, -biǹ in Tula nibiǹ 'seven' may be related to -wiǹ 'one' as plural to singular. A similar situation exists in Jen (Adamawa 9), where 'one' is tsuy and 'two' is represented in 'seven' by vyuy. (Jen has bos 'two', perhaps from *b-or-o(p), comparable with Tula yorau except for the initial prefix.)

In general, the identity of the two roots would have been obscured by assimilative phenomena connected with the presence of a nasal affix in 'one'. This points to original Adamawa forms such as $\sim$ KUU-YID-(N) 'one' and $\sim$ *YID-AB 'two'.

It was, suggested above that the Cross River/Plateau root for 'one' was *DI. We may now hypothesise that the root for 'two' in the proto-language for these groups was the plural *BA-DI, and that, when ProtoBantu developed its more complicated class system, this term, whose prefix may have been invariable, was reinterpreted as monomorphemic. 


\subsection{2. 'Two' $<$ prefix $+{ }^{*} I T O$}

Another set of exceptional cases is the one in which the words for 'two' seems to derive from *ITO with a prefix. This seems likely to be the result of analogy with the form of 'two' in 'seven' (usually compounded of 'five + (connective + ) two').

When the prefix is s-, the source seems to be a root *SA which sometimes replaces the original *NUN as 'five'. The meaning of this root may have been 'one' in the sense of 'entirety, totality'. This explains why it can replace 'five' ('one hand of five fingers'), but can be found for 'one' in other languages. Griaule's Pape cautions against this hypothesis, however. In this language, 'one' and 'five' are probably both represented by sa with different tones. The source of each may thus be different.

Elsewhere, prefixes are found to be z- (Mumuye, Adamawa 5, and Juman, Adamawa 14), t- (Kumba, Adamawa 5), k- (Gengle/Kugama, Adamawa 5), and 1- (Bolgo/Koke, Adamawa 13). The source of these remains to be determined. See also the case of Yungur/Roba (Adamawa 7), where an unidentified prefix f- or fa- is used with different roots for both 'one' and 'two'.

\subsection{Numeral systems in Adamawa group $A$}

\subsection{1. 'One'}

The root for 'one' varies:

Pere group: the root is related to the one in Dii.

Vere/Dowayo/Voko: Sewe gbunnu, Namshi gunu, Dowayo binnu, and even Voko wunga (see 2.1) are likely cognates. However, Vere mbojo or muune $\sim$ muunə appears closer to the common Bantu root for 'one'.

Dii: has a root reconstructible as $\sim$ *DÀKÀ whose origin is undetermined (it seems also to appear in Chadic Bata in the root for 'six', tú-kol-dááká, probably < túf 'five' + connective + 'one'). This root has been replaced in some languages of the Pape subgroup. See also Strümpell's 'Southern Duru' coy, to be compared with the root used in the Southern group of Adamawa 6 (see 2.1).

Chamba Leko group: while nîy could be a nasalised form of the Pere/Dii root, it is phonetically much closer to the forms used in Plateau 2.

Mumuye group: two reconstructed roots, ${ }^{*}$ GBÉTÌ and $*$ GÒRV́, likely to be related to the Vere-Dowayo roots.

Yendang group: a root $\sim^{*}$ BIN(D)I should be related to the Mumuye and Vere/Dowayo/Voko forms.

Kam: bımbini appears to be a reduplicated form of the preceding.

\subsection{2. ' $T W O$ '}

A single root, reconstructible as $\sim * \bar{I} T V$. 
Note evidence of prefixing in Voko (sitto), Mumuye (ziti), and the Yendang group languages, Kumba (tiri) and Gengle/Kugama (kiri).

\subsection{3. 'Three'}

A single root, reconstructible as $\sim *$ TĀTV or *TĀTV. (Gengle/Kugama has a prefix ka-.)

\subsection{4. 'Four'}

A single root, reconstructible as $\sim^{*}$ NATV (Gengle/Kugama prefixes ka-).

\subsection{5. 'Five'}

The most widely used root is reconstructible as $\sim^{*}$ NÚN. Exceptions are:

Vere: gbona- (may be related to the root for 'one' in the Dowayo group i.e. 'one hand');

Pape subgroup: sa;

Mumuye group: *MÀÁŃÍ (related to the Bantu root for 'one', i. e. 'one hand'?).

The root in the Yendang group seems to be the reconstructible one (with prefix gi(ka- in Gengle/Kugama)). It should be remarked, however, that (in the absence of tones) there appears to be homonymy between 'hand' and 'five' in some languages.

\subsection{6. 'Six'}

The term for 'six' is frequently a compound: 'five one' (with no connective). This is so in Pere and Vere-Dowayo (for Vere, the composition is clear in Strümpell, but is masked by various developments in later data). In the Dii group, there is a root reconstructible as *GÚÚ. This root is likely to be cognate with 'one' in the Dowayo group. Diachronically, this may be an earlier Dii root for 'one'; when replaced by *DÁKÁ in this sense, it could be used unambiguously for 'six' without being compounded with 'five'. Note, however, that in the Pere group, the cognate of *DÁKÁ is used for both 'one' and 'six' (in compound with 'five').

The exception among the Duru languages is Voko, which uses same, remindful of Proto-Bantu *-cààmànò; but compare Jarawan -(tụ.)sal.mo 'six' ('five' + connective + 'one'), apparently the source of (se)sama 'six' in the now extinct 'Bantoid' Nagumi. (Further afield, there is a root samma 'one' in Guera Gula (Adamawa 13), but the connection is tenuous.)

According to Griaule, the root for 'seven' has replaced 'six' in his Pape. The same has happened in Strümpell's Leko.

The Leko languages form 'six' from 'five' + * GÚÚ + a suffix (?) (A)S(A) (see 2.1, but also compare with Voko and 'five' in the Pape subgroup of Dii languages).

In Mumuye, 'six' is 'five one', but in the Yendang group apparently 'five connective one'. The connective seems to have the form $\sim^{*}$ GAT. In some languages, including 
Yendang itself, 'five' has been dropped. The original form appears only in Kumba and Gengle/Kugama.

Kam uses a form (probably joop) which may be cognate with *GÚÚ + a suffixed element (see 2.1).

\subsection{7. 'Seven'}

The term for 'seven' may be compounded from 'five two' without a connective, but this is fairly rare. It appears in the Dowayo subgroup of Duru languages, in Wom, Mumbake, and Kolbila in the Leko group, and in Mome, a Mumuye language recorded by myself (máàn zit).

In some languages, 'seven' contains the root for 'two' with a prefix, probably reconstructible as $\sim *$ SA, which should be compared with similar forms cited under 'five' and 'six' above. The clearest example of this type is provided by Strümpell's Vere, where 'two' is etu.lo (the common root with a suffix), and 'seven' is setu.lo. This is therefore simply a variant of the 'five two' type. (Compare Blench and Edward's gbansa, composed of 'five' and the element *SA, with 'two' removed.) Chamba Leko dialects using 'five' + sínà? or sen to form 'seven' may have obtained the second part of the compound in the same way, although this is disguised by nasalisation of the intervocalic/final consonant, which prevents the identification of the root for 'two'. This is certainly the compounding procedure followed in all the Yendang languages (except Gengle/Kugama, see below), although the prefixed element is $\mathbf{t}$ - rather than s-. (In Kumba, the order gi- + 'five' $+\mathbf{t}-+$ 'two' is permuted to give 'five' + gi- $+\mathbf{t}-+$ 'two'.)

Prefixing by analogy with the form of 'two' in 'seven' is presumably one cause of the appearance of exceptional forms such as those cited above under 'two' (see 2.2.2).

Given that *SA $+* \bar{I} T$ - can yield forms like set, the problem is to be sure in each case that we are not dealing with some sort of morphological variant of the root 'three' (*TĀT-), which is clearly present in some languages, particularly Mumuye, where náwàtat seems to be connective + 'three'. The structural source of such forms is likely to be as in Gengle/Kugama, where oga nat oga sat is probably to be glossed 'four on one side, three on the other' (i. e., when counting is done on the fingers, seven is shown by joining four fingers on one hand and three on the other). Most languages use a shortened form, obtained by eliminating the reference to the hand showing the complete set of four fingers.

This arrangement should be compared with another possible use of 'three' (as in Adamawa 6), where three is the number needed to make ten. This requires that counting the numbers after 'five' be based on the representation of 'five' as a full hand of four fingers and the thumb. Only the number 'eight' will show with certainty which system is involved: 'eight' will be based on 'four' in the former case, and 'two' in the latter. 
The forms in Kutin (dómsārā) and Voko (saranga) are of obscure origin but may be related. They may be derived from 'three', but could also be abbreviated borrowings from Jarawan Bantu 'seven' ( tuy.sal.bari 'five' + connective + 'two').

Another way of forming 'seven' is to compound on the root for 'six'. This occurs in the Duru languages in which 'six' is not already a compound (the Dii group). An element of

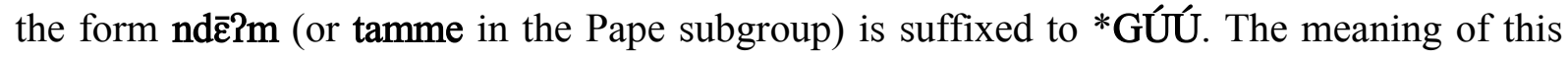
element has not been determined.

In Kam, 'seven' is composed of 'two' and a variant (jub-) of the probable cognate of *GÚÚ used for 'six'. This suggests that 'six' was somehow interpreted as 'five one', from which 'five' could be extracted to form 'seven' as 'five two'.

The root for 'eight' replaces 'seven' in Griaule's Pape and Strümpell's Leko (where 'seven' has already replaced 'six'), and in Patapori as reported by Williamson.

In Strümpell's Sari, Pape, and Namshi, the term for 'nine' is given for 'seven'. Unlike the preceding cases, this could be an error of notation, as no number higher than 'eight' is recorded for these languages.

\subsection{8. 'Eight'}

It is rare for 'eight' not to be a compound of 'four'. A few languages do, however, form 'eight' from 'five three' without connective. These are Griaule's Sewe and Namshi (in the Duru group), Kolbila in the Leko group, and Kumba in the Yendang group. Also compare Strümpell's Vere, where 'eight' is composed of *SA + 'three' (Blench and Edwards have samsara, where sam- suggests a relationship to a reflex of Proto-bantu 'five': see Voko 'six' above). Kam sal should be of the same origin (this root is also present in 'Bantoid' Suga/Nyamnyam, which may, however, be the borrowing language).

In languages which form 'eight' from 'four', the structure is generally 'connective + four'. In the Dii group of Duru languages, the meaning of this connective has been identified as 'beside'. The original structure is thus likely to be as in Kengle/Kugama in the Yendang group 'four on one side, four on the other' (see 'seven').

In Mumuye, 'eight' has the same structure as in the Dii group, but the connective has not been identified. In the Yendang languages other than Kumba and Gengle/Kugama, the connective may be a root for 'two', bar- (borrowed from neighbouring languages?).

Some languages have a special root for 'eight', of unknown origin. A root possibly reconstructible as -*DÀKO is present in the Pere and Leko groups, although Mumbake in the Leko group has durtia (likely to be a compound). There is also Dowayo gese, and Duru Mbukma tanma (perhaps somehow related to 'three').

In two languages, Voko and Griaule's Pape (both in the Duru group), the root for 'four' is followed rather than preceded by a connective, whose meaning has not been determined. 
See also Wom fatfat, borrowed from Chadic (literally 'four four').

In Griaule's Kutin and Strümpell's Leko, the term for 'nine' replaces 'eight'. In Patapori, where 'eight' has come to mean 'seven', a new term for 'eight' is compounded from the original root and a preceding connective of undetermined meaning.

\subsection{9. 'Nine'}

The basic structure of 'nine' is almost always 'remains/lacks hand one', although this is reduced in some languages to 'remains one', 'remains hand', or 'hand one'. In the Duru group, this stucture is found in Kutin, Vere, probably Dowayo, and most of the Dii group. It is also found in Noss's Leko, Wom, and Mumbake (in the Leko group), in Mumuye (with an exceptional use of the root ${ }^{*} \mathrm{BE}$, rare in Adamawa, for 'hand' ??), in Teme and Waka (in the Yendang group; there is doubt about whether 'remains' cannot be further segmented into 'remains ten' in this case), and probably in Kam (although the structure is 'hand + undetermined element').

It is nevertheless possible to find isolated cases of 'five four': in Sewe/Namshi (Duru group), the Mumuye dialect Mome, and Kumba (Yendang group). See also Gengle/Kugama, which counts 'four on one side, five on the other'.

There is a wide variety of special cases:

In Griaule's Kutin (Duru group), where the original 'nine' of the form 'remains one' has become 'eight', a new 'nine', apparently of the same structure, has been compounded.

In Patapori, 'nine' is given as demsa, which strongly resembles the root for 'seven', but may nevertheless be some sort of compound with 'one' as its initial element.

Duru Mbukma tame ndaro seems to be compounded with 'four', but the first element may or may not be related to 'eight' (see above).

Meek's Chamba Donga (Leko group) seems to have a special root for 'nine', light (origin unknown). His Chamba Leko seems to use 'eight + unidentified element (related to *GÚÚ?)'.

The Yendang nóśk̄̄m tāt, which, segmented in this way, seems to make use of the root for 'three', has no immediate explanation. It is the root to be expected for 'seven' (see Patapori above).

In Strümpell's Leko, the root for 'ten' has been replaced by the term for 'nine'.

\subsubsection{0. 'Ten'}

The most widespread root is reconstructible as $\sim^{*}$ KÓP. It appears in the Duru group (with suffix) in Vere and the Dowayo subgroup, and throughout the Chamba Leko, Mumuye and Yendang groups. (It is also present in Adamawa 1 and 10, whence it may have been borrowed by Plateau groups 1 and 2). 
There is another root, $\sim^{*}$ BÓ or *BÓ, which appears in the Dii group (Duru), always with a prefix except in the Pape subgroup, and in Kam. This root may be borrowed from Chadic.

The Kutin group has fop, which may be related to * KÓP.

In Strümpell's Leko, where the root for 'ten' bas taken on the meaning 'nine', a new term for 'ten' is compounded from the original root, followed by an element of unidentified origin (beri).

\subsubsection{1. 'Eleven' to 'nineteen'}

In all languages, these numbers are compounds having the structure 'ten + connective + (one to nine)'.

In Kutin, this connective is identifiable as 'with', but in other languages (such as Dii and Mumuye), it seems to have no other function in the language and is thus of unknown origin.

In Voko, the root for 'ten' seems to have been dropped, so that only the connective $(\operatorname{dad} \partial(m))$, followed by the numeral, remains.

In Strümpell's Leko, the original uncompounded root for 'ten' (used for 'nine') is employed in these numbers, rather than the derived compound form.

\subsubsection{2. 'Twenty'}

The data for a certain number of languages are not available.

In Kutin, according to Griaule's notes, 'twenty' seems to be 'mouth one'. In Griaule's Sewe and all of Meek's Leko languages, the compound seems to be 'head one'. In both cases, the sense is 'one person'.

According to both Noss and Strümpell, Chamba Leko also compounds 'twenty' from 'one', but the first term of the compound (laa for Noss, t $\varepsilon$ for Strümpell) remains unidentified.

All the Dii languages (Duru group) seem to use a root gbek, possibly a borrowing of a Chadic root for 'two'.

The Mumuye group has *BMÀTI, which is likely to be cognate with the ma and mi which appear in the Yendang group. There may also be a relationship with the maa ju (second element 'head' ?) recorded in Pape by Griaule. In Mome, however, 'twenty' is láá mát, where the first element should be compared with Leko and the second seems to act as 'one' (thus 'one hundred' is láá māānîn 'twenty five'). This root should therefore be compared with the reconstructed root for 'five' in the same group, and hence to the Bantu root for 'one'.

The structure of Voko jug yo may be the same as in Pape.

The origin of Kam paimi is undetermined. 


\subsubsection{Duli and Gewe}

Note: two closely related languages in the Duru group have lexically idiosyncratic number systems, although compounds are formed in an ordinary way. Lists of numbers in these now probably extinct languages are available from Strümpell (Duli) and Baudelaire (Gewe, Duli). They are as follows:

hira or hita 'one', which may be a reflex of the common Adamawa root, but is more likely of Chadic origin;

sik 'two' could be the common Adamawa root with prefix s- (compare Voko) and final $\mathbf{t}>\mathbf{k}$, but this is speculation;

ba 'three' is of unknown origin (compare Cham bwanbí in Adamawa group 1);

fwon or mofon 'four' is clearly Chadic;

nakkam or nak(k)ani 'five' is not clearly related to any family;

naani or naa tanu or na tadiu 'six' is compounded with 'five' and another undetermined element (resembling Adamawa 'three' !);

naasik or nar gasik 'seven' is 'five (connective) two';

naaba or nar gabia or nar gasba is 'five (connective) three';

naafoon or nar ga(s) fwon 'nine' is 'five (connective) four';

bo 'ten' is the Adamawa/Chadic root;

byeg 'twenty' is the Duru root (perhaps borrowed from Chadic 'two').

\subsection{Numeral systems in Adamawa group 6}

\subsection{1. 'One'}

The root is stable (probable reconstruction: *MBÉW). Exception: Southern group són.

\subsection{2. ' $T W O$ '}

The root is variable:

Mundang, Pam/Mono: ga?. Perhaps related to Mambai -nàt representing 'two' in 'twelve' (Mambai 6ati 'two' may be obtained by prefixing bi-, also prefixed to all numbers from 'three' to 'six').

Tupuri boke is a Chadic loan.

Kali đémà, probably related to a root for 'ten' below.

Southern group dúà (related to the Kali form ?).

Elsewhere sídà (compare 'two' and 'seven' in Adamawa group A).

\subsection{3. 'Three'}

Stable root reconstructible as *SĀPI. Exception: Southem group mòkón (certainly borrowed from a Chadic term for 'three'). 


\subsection{4. 'Four'}

Stable root, though some languages have reflexes of Adamawa *NAR and others of $\sim^{*}$ NYAR, which are likely to have been morphological variants at one time.

\subsection{5. 'Five'}

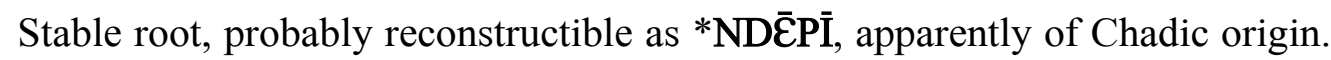

\subsection{6. ' $\mathrm{Six}$ '}

Generally a root reconstructible as $\sim * \mathrm{JA}$ or $\sim * \mathrm{~J} \hat{\varepsilon}$. Exceptions are:

Tupuri hira, Mundang bì.gírò are likely loans of a Chadic root for 'one'.

Kali subgroup: sara, probably a morphological variant of 'three'.

Karang tótśkló, apparently from the expected tòy ndók 'remain hand' and perhaps nay 'four' with assimilated consonant and harmonised vowel (though Karang has nìn 'four'; nay is the form found in the Northem group).

\subsection{7. 'Seven'}

In the Central and Southern groups, 'seven' is a compound of the form remain hand three.

The Northern group has a variety of forms. In the Kali subgroup, nàr sāy may be 'four (?) three'. Tupuri harnam and Mundang tàrnák are borrowed from Chadic Gisiga or a closely related language. Mundang rin is of unknown origin. Pam/Mono sídâ is certainly the same as 'two' above.

\subsection{8. 'Eight'}

In the Central and Southern groups, 'remain hand two'.

The Northem languages use a morphological variant of 'four', perhaps reconstructible as *NĀNMÀ. Exceptionally, Mambai fwărnàà seems to be '(Chadic) four + (Adamawa) four'.

Exception: in Lacroix's Galke, 'nine' replaces 'eight'.

\subsection{9. 'Nine'}

The Southern and Central languages use 'remain hand one'.

Among the Northern languages, Galke shows the original form: à-ndú-mbó from prefix à-, ndúl 'hand', mbó 'one' (In Lacroix's Galke, where 'nine' has become 'eight', we find 'hand two'!). This appears as derbo in Mono. In the other Northern languages, there is a metathesis of the intervocalic consonant group.

Exceptions: Mambai séé bóm is compounded from 'one' and an unidentified element. Tupuri kawa is of unknown origin, but may somehow be related to the Tupuri root for 'ten'. 


\subsubsection{0. 'Ten'}

Central and Southern languages have bǒ (compare with 'ten' in Adamawa 4/8). An exception is Koh dùo, perhaps related to the word for 'two' in the Southern group.

Northern languages use jémmà. Exceptions are Kali (which uses this root for 'two' and borrows bo from the Central group; Mbai zódôm (of unknown origin); and Tupuri hi.kwol or kwal, which resembles the common Adamawa root, but may be unrelated (see also 'one', 3.1).

\subsubsection{1. 'Eleven' to 'nineteen'}

All Central and Southern languages, plus Kali, Dama, and Galke, use 'ten + back (i. e. after) + 1-9' (an additional morpheme kù follows 'back' in Dama and Kali). The structure is the same in Pam/Mono and Mundang, probably with 'head' (i. e. 'over') for 'back' (+ kù). Mambai and Tupuri use connectives of undetermined origin.

\subsubsection{2. 'Twenty'}

Almost all languages use 'ten two' (Tupuri reduplicates 'ten'). Exceptions: Kali and Mambai use 'head two'; Dama uses bek borrowed from Duru; Koh uses an unidentified root sín + 'two'.

\subsection{Conclusions}

The data presented above for Adamawa groups A and 6 suggest the following conclusions.

\subsection{1. 'One', 'two' and 'five'}

In groups with considerable dialect variation, the roots for 'one', 'two' and 'five' are liable to replacement. In the smaller Adamawa groups where there is less diversification, these roots seem quite stable. This is why they can be reconstructed for the branch as a whole.

\subsection{2. 'Three' and 'four'}

The roots for 'three' and 'four' are extremely stable and replaced only rarel by evident borrowing from Chadic.

There must be semantic and sociolinguistic reasons for this difference in stability. One might be the association of 'three' and 'four' to the notions of 'male' and 'female'. It is, however, extremely difficult to envisage ways of proving which such factors are at work.

\subsection{3. 'Six' to 'nine'}

The numbers from six to nine are generally compounds. The even numbers, six and eight, are, however, sometimes not decomposable. When 'six' is a compound, it is almost always 'five + (connective) + one' (although there is apparently one case of 'remains hand four'). 
In the whole Adamawa branch, only one language (Longuda, Adamawa 10) seems to use 'three three'.

When 'six' is not decomposable, it may be derived from a special form of the root for 'one', after removal of a previously present 'five'.

In certain cases, however, 'six' may be a former morphological variant of 'three'. In Adamawa group 13, Lwa (Niellim), Bua, and a few other dialects derive 'six' from 'three' by vowel sandhi (perhaps reflecting an earlier difference of affix; compare Meek's 'hill dialect' of Longuda, which shows a more coherent and perhaps older system than other recorded varieties). Unusually, they use a similar process to obtain 'seven' from 'five'. The Kali subgroup in Adamawa 6 also has a form for 'six' which may be derived from 'three' by change of suffix. This suggests the original contrast may have been of the singular/plural type, so that these cases are a sort of variant of 'three three'.

When the roots for 'six' (and sometimes 'eight') are not decomposable, the following number may be formed from them by compounding with an additional element.

'Seven' is often compounded of 'five' and 'two', but more rarely of 'four' and 'three' (also found elsewhere in Adamawa: in Longuda and Day) or even 'remains hand three'.

When the root for 'eight' cannot be decomposed, it may be a former morphological variant of 'four', derived as 'six' may be from 'three'. In other cases, however, its origin cannot be determined from the available data.

When 'eight' is compounded, it may consist of either 'five three', 'four four', or (in one case) 'remains hand two'. In Adamawa group 5, the use of 'four four' is compatible with 'five one' and 'five two' for 'six' and 'seven', respectively. If this reflects gestures of counting on the fingers, the thumb must be made to coincide with the fingers on one hand from 'five' to 'six' or 'seven', but contrast with them in 'seven' and/or 'eight'.

'Nine' is usually compounded with respect to the notion of 'ten', or completion of the fingers on the hand(s). Some cases of 'five four' are also found, but never when 'eight' is not itself a compound.

\subsubsection{Lowering}

The preceding generalisations can be falsified by 'lowering'. This consists of replacing a number from six to nine by the immediately higher one. A succession of lowerings may take place until a new term replaces a lowered number. This new term may be compounded from. the lower one it replaces.

Examples of lowering appear among the earliest data collected on these languages. Is there a possibility that these examples are simply an error on the part of the investigator? This is unlikely, (1) because similar cases were recorded by independent investigators over a thirty-year time span, and (2) because the lowering process is not haphazard (as if the order 
of the numbers had been confused), but systematic, involving substitution at a given point of a new and coherently structured term. Finally, my recently collected data on Chamba Daka dialects entirely confirm the case of lowering recorded by Meek in the same group. These data are presented here in Appendix 1.

Lowering is not a geographically widespread phenomenon. It seems to be localised in the two Chamba languages and the contiguous eastern part of the Duru group (although there is also an isolated example in group 6, and a case has been recorded in supposedly Adamawa Fali). There must be semantic and sociolinguistic reasons for this process, which may be different in each case, as the number removed from the system. is different.

\subsection{5. 'Ten'}

There are two roots for 'ten'. The most widespread (*KOP) may be the original Adamawa root (but compare Hausa gomà 'ten' ?); the other (*BO) may be a Chadic loan.

\subsection{6. 'Eleven' to 'nineteen'}

The numbers from eleven to nineteen are compounded from 'ten' and the numbers from 'one' to 'nine', with a connecting element which is often either 'with' or the term for a body part having a locative sense.

\subsection{7. 'Twenty'}

'Twenty' may be compounded either with 'one' in the sense of the fingers and toes of one person, or with 'two' in the sense of two tens (even if the root representing 'ten' is not the same in 'ten' and 'twenty').

\subsubsection{Counting gestures}

The number systems described suggest certain correlations with the gestures used for counting. Two major types emerge: those which associate the thumb with the fingers of the same hand for every number from 'six' to 'nine', and those which dissociate it. The latter system may imply that counting from 'one' to 'five' is done on one hand and 'six' to 'nine' or 'ten' on the other; while the former may involve using one hand for displaying fingers and the other for manipulating the fingers displayed. These hypotheses remain to be confirmed.

It would furthermore be interesting to survey the gestures of counting in a selection of the Adamawa languages, to see whether they invariably correlate with the linguistic data. If discrepancies are observed, it may be that terms which the linguist analyses as compounded are no longer felt to be so by native speakers. The question will also be raised whether a new gesture system has been imposed on an older linguistic base, and whether this can ultimately give rise to a restructuring of the latter. 


\section{BIBLIOGRAPHY}

Anonymous. 1955/6. Grammar of the Tula language (Northem Provinces, Nigeria). By a missionary, edited by J. Lukas. Afrika und Übersee 39(3): 101-18, 39(4): 149-68.

Baudelaire, H. 1944. La numération de 1 à 10 dans les dialectes Habé de Garoua, Guider-Poli et Rey-Bouba. Bulletin de la Société d'études camerounaises 5: 25-30.

Bennett, Patrick R. 1983. Adamawa-Eastern: problems and prospects. In Current Approaches to African Linguistics I, ed. by I.R. Dihoff, pp. 23-48. Dordrecht: Foris.

Blench, Roger, Adrian Edwards et. al. 1988. A Dictionary of the Momi Language. (Provisional unpublished data.)

Bohnhoff, Lee. 1972. Dictionnaire duru / Duru Dictionary. Mimeographed. Ngaoundéré.

Boyeldieu, Pascal. n.d. Unpublished material on Lwa (Niellim).

Fabre, Anne Gwenaëlle. 2003. Études du samba leko, parler d'Allani (Cameroun du Nord, Famille Adamawa. Lincom Studies in African Linguistics 56. München: LINCOM.

Gaudefroy-Demombynes, M. 1907. Documents sur les langues de l'Oubangi-Chari. Paris: Leroux.

Greenberg, Joseph. 1966. The languages of Africa. Bloomington: Indiana University.

Griaule, Marcel. 1941. Vocabulaires papé, woko, koutinn, namtchi et séwé du Cameroun septentrional. Journal de la Société des Africanistes 11: 169-85.

Jungraithmayr, Hermann. 1968/9. Class languages of the TangaIe/Waja District (Bauchi Province, Northern Nigeria). Afrika und Übersee 52 (3/4): 161-206.

Lacroix, Pierre-Francis. 1962. Note sur la langue galke ("dáí). Journal of African Languages 1 (2): 94-121.

Meek, C. K. 1931. Tribal Studies in Northern Nigeria. 2 vols. London: Kegan Paul.

Mouchet, Jean. 1938. Vocabulaires comparatifs de 15 parlers du Nord Cameroun. Journal de la Société des Africanistes 8 (2): 123-43.

------. 1954. Esquisse grammaticale du parler juman. Bulletin de l'Institut d'Etudes Centrafricaines, nouvelle série (Brazzaville), 7/8: 171-85.

Noss, Philip. 1976. Samba-Leeko: outline of phonology. Bulletin de l'Atlas Linguistique du Cameroun 2: 5-38.

Nougayrol, Pierre. 1980. Le day de Bouna (Tchad): II. Lexique day-français, Index français-day. Paris: SELAF.

Pairault, Claude. 1969. Documents du parler d'Iro, kùláál du Tchad. Paris: Klincksieck.

Raen, Konstanse. 1985. Dictionnaire pArAE-français. Ngaoundéré: Église évangélique luthérienne du Cameroun.

Rendinger, General de. 1949. Contribution à l'étude des langues nègres du Centre Africain. Journal de la Société des Africanistes 19 (2): 143-94. 
Shimizu, Kiyoshi. 1979. A Comparative Study of the Mumuye Dialects (Nigeria). Berlin: Dietrich Reimer Verlag.

----. 1983. The Zing Dialect of Mumuye: a Descriptive Grammar. Hamburg: Helmut Buske Verlag.

Strümpell, F. 1910. Vergleichendes Wörterverzeichnis des Heidensprachen Adamauas. Zeitschrift für Ethnologie 3/4: 444-88.

-----. 1922/3. Wörterverzeichnis des Heidensprachen des Mandaragebirges (Adamaua). Zeitschrift für Eingeborenen Sprachen 13 (1): 47-75; 13 (2): 109-49.

Ubels, Edward. [1981?]. A Comparative Study of Koh and Karang. Mimeographed. Summer Institute of Linguistics.

Williamson, Kay. 1973. Benue-Congo Comparative Wordlist. Volume 2. Ibadan: West African Linguistic Society. 
APPENDIX 1: The numeral systems of the Chamba Daka languages

\section{A.1.1. 'One' to 'five'}

The Chamba Daka languages were excluded from the Adamawa branch on the basis of a lexicostatistical study (Bennett 1983), suggesting that Greenberg (1966) made only one mistake in the whole of Niger-Congo. In fact, mass comparison is one procedure and lexicostatistics is another. One cannot impact on the other, and these languages must remain where Greenberg put them from a mass comparative standpoint.

Lists of numbers in several of these languages are available from Strümpell (1910) and Meek (1931). Meek's data for Taram and Dirim are compared below with my own data for the widely spoken Nnakenyaare dialect ( Strümpell's and Meek's Chamba Daka) and the dialect spoken in the Nigerian town of Mapeo.

$\begin{array}{lll}\text { Chamba (Mapeo and Nnakenyaare) } & \text { Taram/Dirim } & \\ \text { nòòn } & \text { nwan } & \text { 'one' } \\ \text { bààrá } & \text { bara } & \text { 'two' } \\ \text { tárā } & \text { tara } & \text { 'three' } \\ \text { nààsá } & \text { nasa } & \text { 'four' } \\ \text { túùná } & \text { tonona/toona 'five' }\end{array}$

The Chamba Daka root for 'one' may be cognate with the root in Chamba Leko. Speakers of languages from both groups have lived in close cultural contact (whence the common element, Chamba, in their names), so the possibility of borrowing exists.

The Chamba Daka root for 'two' is more characteristic of Benue-Congo than of Adamawa.

The root for 'three' is the common Adamawa one, but is shared with the whole of Niger-Congo.

The root for 'four' is represented in all of Niger-Congo. In Adamawa, the intervocalic consonant is generally of the $t / d / r$ type; $s$ is, however, found in the Sewe-Dowayo subgroup of Adamawa group 4.

The term for 'five' clearly resembles the form characteristic of Jarawan Bantu and some Plateau groups, suggesting an original $\sim$ *TUKUNØ (perhaps *TUKU-NØ, where the second element is cognate with the Adamawa root). It would seem from the data for 'six' and 'seven' that, after nasalisation of the intervocalic velar in an ancestor of Chamba Daka, 'five' was understood to be compounded from an initial *tuN-.

\section{A.1.2. 'Six'}

Chamba túnìn, perhaps from 'five one' by vowel assimilation. The same term appears in all dialects except Taram ka nwan, clearly compounded from 'one'. 


\section{A.1.3. 'Seven'}

Mapeo Chamba dùpó?, Nnakenyaare Chamba dùtím. The former is the root for 'eight' in Taram and Dirim. Their roots for 'seven' are respectively kım bara and tum bara, both composed of 'two' and an initial element which is cognate with the initial element in 'five' and 'six', if $\mathbf{k}$ has become $\mathbf{t}$ in Taram (compare $\mathbf{k a}$ in 'six', where the a may be the result of harmonisation with the vowel in nwan 'one'). The Nnakenyaare form should be compared with durtia 'eight', recorded by Meek in the Leko language, Mumbake (although -tím may somehow be related to 'five').

\section{A.1.4. 'Eight'}

Both Chamba languages compound with the original term, now meaning 'seven'; thus dùpó kórórá and dùtím kóróró.

\section{A.1.5. 'Nine'}

Mapeo Chamba uses nòòn bé-gèn 'one be-where?'; Taram and Dirim have kpa nwan. Both are clearly compounded with 'one' and therefore of the type 'remains hand one'. There may be a relationship between Taram/Dirim kpa and wa 'arm' (Chamba wáā).

Nnakenyaare Chamba uses the root for 'ten', kúum. This should be compared with Strümpell's Chamba Leko.

\section{A.1.6. 'Ten'}

Mapeo Chamba kúūm, identical with Taram and Dirim. Nnakenyaare Chamba recompounds from 'nine’: kúūm kóróró. (Compare ProtoBantu *-kúmì ‘ten'.)

\section{A.1.7. 'Eleven' to 'nineteen'}

All languages return to kúūm as 'ten', followed by the connective bàà and the numerals from one to nine. The connective is not identifiable, although a relationship with the verb 'come' is not impossible.

\section{A.1.8. 'Twenty'}

The Chamba dialects have mūm nòòn 'mouth one'. Taram and Dirim have no for mūm; this root (nū:, homophonous with the term meaning 'feminine') reappears in the Chamba dialects from 'forty' onwards.

\section{A.1.9. Chamba and Tiba}

Tiba (Boyd 1999a,b) was not known to Greenberg. It has been erroneously grouped with Chamba owing to the extent of invasion of Chamba loanwords. A closer look nevertheless shows that its place is actually in Adamawa 5. Its numeral system is therefore included with the languages of this group in Appendix 2. It will be noted, however, that 'one' has a velar 
prefix (cf. Munga and Burak vs. the labial prefix in Yendang). 'Two' has a labial initial consonant and might be related to the Chamba form given below. Chamba loanwords are, however, usually straightforward in their correspondences. Here, both initial consonant and first vowel vary inexplicably. One possibility would be that both languages took this numeral independently from a Benue-Congo source at an ancient date. Another would be that -ē:r is just the common Adamawa root and that 6- is a prefix as in Mambai. 'Three' and 'four' correspond well with the rest of Adamawa 5, but 'five' has the same unvoiced initial stop and falling tone on the first syllable as Chamba, which again seems to suggest a BenueCongo source. 'Ten' corresponds to Adamawa 5 with $\mathbf{k}>\mathbf{k w}$ (cf. Adamawa 1 and 2) $>\mathbf{w}$. In Tiba as in all of Adamawa, 'twenty' is not a comparable root. 
APPENDIX 2: Numerals in selected Adamawa languages

\begin{tabular}{|c|c|c|c|c|c|c|c|}
\hline & & 'one' & 'two' & 'three' & 'four' & 'five' & 'six' \\
\hline \multirow[t]{2}{*}{ 1: } & Tula & wiǹ, -iǹ & rop & táa & naa & nu & nukuǹ \\
\hline & Awak & $\operatorname{din}$ & yóró & kunún & ńńa & fwáát & (idí )kúún \\
\hline \multirow[t]{2}{*}{ 2: } & Samba Leko & nîn & ì:rō & tō:rō & nā:rā & núnā? & nôygós \\
\hline & Mumbake & nina & ira & tara & n $\Lambda$ ra & nuna & noyse \\
\hline \multirow[t]{6}{*}{ 4: } & Pere $(=$ Kutin $)$ & də́ə & iro & ta:ro & naro & nu:no & nóndə́ə \\
\hline & Vere & kumboko & etulo & taroko & nato & benaro & bena mbojo \\
\hline & Sewe & gbunnu & ere & ta:re & naso & no:ne & non gunu \\
\hline & Voko & wunga & sitto & ta:bo & nanue & nombo & sa:me \\
\hline & Dii (= Duru) & dágá & idú & ta:nó & ndadú & nónó & gú: \\
\hline & Pape & sa & ito & tato & nato & $\int \mathrm{a}^{\mathrm{a}}$ & gutamme \\
\hline \multirow[t]{6}{*}{ 5: } & Proto-Mumuye & *gbéti/*goró & $*_{\text {ziti }}$ & $*$ tati & $*$ dne:ti & *mǎńí & \\
\hline & Zing & goró & zit & tat & dne:rò & mǎń & màńgoó \\
\hline & Tiba & kīn & 6ē:r & tárá & nè & tûy & tûn-kīn \\
\hline & Yendang & bíntí & í:nì & tāt & nāt & gìnán & gàtíntī? \\
\hline & Waka & bindi & ini & tat & nat & $\operatorname{gin} \wedge y$ & gatındi \\
\hline & Gengle/Kugama & bini & kiri & kasat & kaîjat & kanoy & kanoy ti bini \\
\hline \multirow[t]{5}{*}{$6:$} & Mambai & bom & bati & bisa: & bina: & bizape?e & bigiro \\
\hline & Pam & bo: & ga?a & say & nay & dəpe & ya \\
\hline & Kali & mbew & dama & say & na?ay & ndibi & sara \\
\hline & Karang & mbéw & séde & sāy & nìn & ndī6i & tótókló \\
\hline & Mbum (Man) & sún & dóà? & mòkón & jàn & ndíbí & jéy \\
\hline 7: & Yungur & fini & fito & tâkın & kurun & wonun & mindike \\
\hline 8: & Kam & bımbini & ira & car & nar & ngwun & jऽıp \\
\hline 9: & Munga & $\operatorname{cin}$ & na io & na tat & na njia & na hmi & hwi \\
\hline 10: & Longuda & kalí-yà & napcôr & napkwé & nappîur & napnwá & napki-napkwé \\
\hline \multirow[t]{4}{*}{ 13: } & Gula (Guera) & handay & hori & $\operatorname{tar}$ & nay & tin & tina \\
\hline & Kulaal & tón & ròk & tò:s & nòrò & lún & lúénṭón \\
\hline & Niellim & búrū & ndīrí & tērí & nìā:ní & lūní & tāàr \\
\hline & Bolgo & bara & rete & teri & har & tiso & tipsi \\
\hline \multirow{3}{*}{$\begin{array}{c}\text { 14: } \\
\text { _: }\end{array}$} & Juman & du & $\mathrm{zi}$ & ta & nda & noy & monongol \\
\hline & Burak & kwin & rap & bunu & net & no:b & na:sin \\
\hline & Day & ngŏy & $\mathrm{d} \check{ }$ & tà & ndàg & sārì & sārì mòn \\
\hline
\end{tabular}




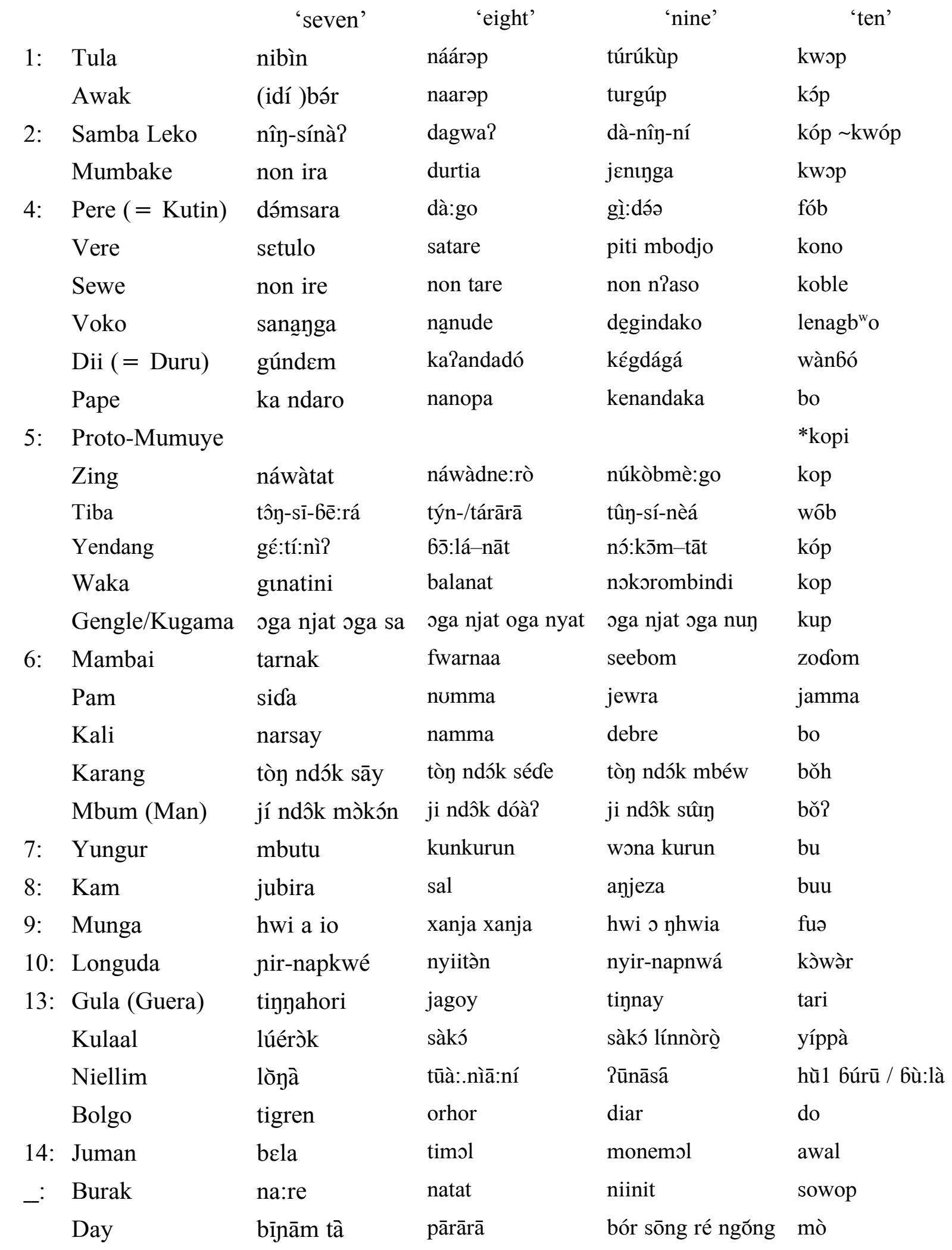




\begin{tabular}{|c|c|c|c|c|}
\hline & & 'eleven' & 'twelve' & 'twenty' \\
\hline \multirow[t]{2}{*}{ 1: } & Tula & kwop Jiri wiǹ & & wani t-uráp \\
\hline & Awak & kóp séré din & & \\
\hline \multirow[t]{2}{*}{ 2: } & Samba Leko & & kwóp-zè-ī:rā & lā \\
\hline & Mumbake & & kwop vuy ira & jillına \\
\hline \multirow[t]{6}{*}{ 4: } & Pere (= Kutin) & fób vəy dáə & dà:go & \\
\hline & Vere & & & djuru \\
\hline & Sewe & koble da gbunnu & & yo bunu \\
\hline & Voko & doduwunga & dadəm sitto & jugyo \\
\hline & Dii (= Duru) & & wàn6ó zù: idú & gbèg \\
\hline & Pape & bojudaga & & maaju \\
\hline \multirow[t]{6}{*}{ 5: } & Proto-Mumuye & & & *bmàti \\
\hline & Zing & kop atú goró & & bmăt \\
\hline & Tiba & & & fé \\
\hline & Yendang & kôp-/tí-bíntí & & mín-bíntí \\
\hline & Waka & kop to bindi & & mi bindi \\
\hline & Gengle/Kugama & kup ta ba bini & & mi bini \\
\hline \multirow[t]{5}{*}{$6:$} & Mambai & zodom som bom & & kaala bati \\
\hline & Pam & & jamma tuko ga?a & jamma ga?a \\
\hline & Kali & & bo marka dama & tul dama \\
\hline & Karang & bǒh fâlú mbéw & & bōn séde \\
\hline & Mbum (Man) & & bǒ kà dóà? & bǔin dóà? \\
\hline 7: & Yungur & bu woha fini & & bu sa fitə \\
\hline 8: & Kam & buu gun bımbini & & paimi \\
\hline 9: & Munga & fuə di tsin & & hwin tsin \\
\hline \multicolumn{2}{|c|}{ 10: Longuda } & kòwə̀r yír kalíyà & & ná na-cə̀r \\
\hline \multicolumn{2}{|c|}{ 13: Gula (Guera) } & tari ya handay & & manday \\
\hline & \multicolumn{4}{|c|}{ Kulaal } \\
\hline & Niellim & lūaà jàm / bù:là búrū & Gùulà / Gù:là ndīrí & hūl ndīrí \\
\hline & Bolgo & dog be bara & & arep \\
\hline 14: & Juman & awal pol du & & wor zi \\
\hline \multirow[t]{2}{*}{$\therefore:$} & Burak & sowop di kwin & & fwa kwin \\
\hline & Day & mò nī P๊̄ ré ngŏng & & mò dīí \\
\hline
\end{tabular}

